\title{
Path of Glucose Breakdown and Cell Yields of a Facultative Anaerobe, Actinomyces naeslundii
}

\author{
By B. B. BUCHANAN* \\ Department of Microbiology, Duke University Medical School, \\ Durham, North Carolina, U.S.A. \\ AND L. PINE \\ Communicable Disease Center, Public Health Service, \\ U.S. Department of Health, Education, and Welfare, \\ Atlanta, Georgia, 30333, U.S.A. \\ (Accepted for publication 27 August 1966) \\ SUMMARY \\ Actinomyces naeslundii fermented glucose primarily by the Embden- \\ Meyerhof pathway, as based on ${ }^{14} \mathrm{C}$-glucose fermentation data and enzyme \\ studies. Enzymes of the oxidative pentose phosphate cycle were also present, \\ but functioned only to a minor extent. Growth on glucose was increased 2- \\ to 4-fold in the presence of substrate amounts of $\mathrm{CO}_{2}$ or $\mathrm{O}_{2}$. This increase \\ was attributed to the additional energy (ATP) made available from the \\ breakdown of pyruvate to acetyl coenzyme $\mathrm{A}$. In the absence of $\mathrm{CO}_{2}$ or $\mathrm{O}_{2}$, \\ pyruvate was reduced to lactate. The weight of organism produced $/ \mathrm{mole}$ \\ ATP $\left(Y_{\mathrm{ATP}}\right)$ was 15-18 g. units under anaerobic conditions with $\mathrm{CO}_{2}$, depen- \\ dent on the growth medium, and 20 under aerobic growth conditions.
}

\section{INTRODUCTION}

Actinomyces naeslundii is a pathogenic organism which,ferments sugars and requires substrate amounts of $\mathrm{CO}_{2}$ for maximal growth. Pine \& Howell (1956) and Buchanan $\&$ Pine (1963) investigated the glucose fermentation of $A$. naeslundii and found that fermentation products depended on the conditions of culture. Without added $\mathrm{CO}_{2}$ (gaseous or bicarbonate), growth was limited and glucose was fermented to lactate

$$
\text { glucose } \rightarrow 2 \text { lactate. }
$$

When substrate amounts of $\mathrm{CO}_{2}$ were present, lactate formation was decreased, and, for each mole of $\mathrm{CO}_{2}$ fixed, an equimolar amount of acetate, formate, and succinate was produced (Pine \& Howell, 1956):

$$
\text { glucose }+\mathrm{CO}_{2} \rightarrow \text { formate }+ \text { acetate }+ \text { succinate. }
$$

The ratio of products with added $\mathrm{CO}_{2}$ was not constant, and dependent upon the specific fermentation a combination of equations (1) and (2) was observed. Based on the average results of three fermentations (Buchanan \& Pine, 1963, table 1, no. 3, 5, and 7), a general equation was derived:

* Present address: Department of Cell Physiology, University of California, Berkeley, California. 
$3 \cdot 5$ glucose $+3 \mathrm{CO}_{2} \rightarrow 3$ formate +3 acetate +3 succinate +1 lactate.

$\mathrm{CO}_{2}$ was fixed into the carboxyl groups of succinate (Pine, 1956, 1960). Presumably $\mathrm{CO}_{2}$ functioned in the formation of oxaloacetate and malate, both of which acted as electron acceptors and permitted the formation of acetate and formate (Buchanan \& Pine, 1963) from pyruvate. $\mathrm{CO}_{2}$ could be partially replaced by either malate or fumarate, with a simultaneous increase in the formation of acetate and formate. Recently, Buchanan \& Pine (1965) found that $\mathrm{CO}_{2}$ was also required for the biosynthesis of aspartate for which the organisms lacked a permease.

When Actinomyces naeslundii grew aerobically, $\mathrm{O}_{2}$ served as an electron (hydrogen) acceptor and $\mathrm{CO}_{2}$ was required only to initiate growth (Pine \& Howell, 1956). Buchanan $\&$ Pine (1963) found that glucose was degraded quantitatively to acetate and $\mathrm{CO}_{2}$ in accordance with the equation :

$$
\text { glucose }+\mathrm{O}_{2} \rightarrow 2 \text { acetate }+2 \mathrm{CO}_{2}+2 \mathrm{H}_{2} \mathrm{O} \text {. }
$$

As based on the above equations, glucose breakdown by $A$. naeslundii might occur by several pathways, and there was until now no evidence concerning which pathway was involved. The present paper presents evidence that $A$. naeslundii ferments glucose principally by way of the Embden-Meyerhof pathway, although the possible operation of other pathways to a minor degree is indicated from isotope data. Previous conclusions about the functions of $\mathrm{CO}_{2}$ and $\mathrm{O}_{2}$ in $A$. naeslundii were confirmed in the present work, and $\mathrm{CO}_{2}$ and $\mathrm{O}_{2}$ are related to the energy which is available for the growth of this organism.

\section{METHODS}

Actinomyces naeslundii (A. bovis, ATcc 10049), described previously (Buchanan \& Pine, 1963), and Actinomyces propionicus (Buchanan \& Pine, 1962) were grown at $37^{\circ}$ in the casitone medium of Pine \& Watson (1959) or in the casein hydrolysate medium of Pine \& Howell (1956). Fermentation products were analysed as described previously (Buchanan \& Pine, 1963). Lactate and succinate were isolated by Dowex-1 column chromatography (Busch, Hurlbert \& Potter, 1952) as modified by Buchanan \& Pine (1963). Purity was established by co-chromatography on paper of a sample of the isolated radioactive acids with authentic lactate or succinate. Chromatograms were developed descendingly by using ethanol + water + concentrated ammonium hydroxide $(80+15+5$, by vol.) as the solvent (Cheftel, Munier \& Machebœuf, 1953). Acids were located as yellow spots against a blue background by spraying the chromatograms with bromcresol green $(0.01 \%(\mathrm{w} / \mathrm{v})$ in] $95 \%(\mathrm{v} / \mathrm{v})$ ethanol in water neutralized to pH12 with $0 \cdot 1 \mathrm{~N}-\mathrm{NaOH}$ ) and by radioautography. In all cases, yellow spots coincided exactly with the darkened areas of the X-ray film. Acetate and formate were isolated by steam distillation and were identified by their Duclaux constants.

For radioactivity determinations, compounds were oxidized to $\mathrm{CO}_{2}$ and counted as $\mathrm{BaCO}_{3}$. Oxidations were done in a combustion chamber equipped with a train of three collection tubes, one of which served as a $\mathrm{KMnO}_{4}$ scrubber $\left(5 \%\right.$ (w/v) $\mathrm{KMnO}_{4}$ in $0.3 \mathrm{~N}-\mathrm{H}_{2} \mathrm{SO}_{4}$ ), leading from the chamber to two tubes containing a saturated solution of $\mathrm{Ba}(\mathrm{OH})_{2}$. Helium was used to! flush the system continuously. The $\mathrm{BaCO}_{3}$ was separated by centrifugation in stoppered tubes, washed three times with boiling water, and suspended in $95 \%(\mathrm{v} / \mathrm{v})$ ethanol in water. Suitable samples were pipetted into lightly greased planchets and dried under heat-lamps. 
Radioactivity was measured with a continuous flow counter equipped with a 'micromil' window. 'Q-gas' $(98.4 \%$ (v/v) $\mathrm{He}+1.6 \%$ (v/v) butane) was used as the ionizable gas. Samples were corrected for background and self-absorption by reference to a standard curve obtained with known amounts of $\mathrm{BaCO}_{3}$.

Succinate, lactate and acetate were wet-ashed by the method of Van Slyke, Plazin \& Weisiger (1951), and the specific activity of the $\mathrm{BaCO}_{3}$ (c.p.m. $/ \mu$ mole $\mathrm{BaCO}_{3}$ ) was multiplied by the number of carbon atoms in the molecule to give the average total specific activity. Formate was converted to $\mathrm{CO}_{2}$ in the presence of acetate by oxidation with mercuric sulphate by the method of Friedemann (1938) as modified by Rabinowitz \& Barker (1956). The residual acetate was collected by steam distillation and its purity verified by its Duclaux constants. Acetate was decarboxylated with the Schmidt reaction (Phares, 1951). After decarboxylation, the solution was made alkaline with $\mathrm{KOH}$, and the methylamine was isolated by distilling into diluted $\mathrm{HCl}$; methylamine was oxidized to $\mathrm{CO}_{2}$ with alkaline permanganate (Katz, Abraham \& Chaikoff, 1955). Lactate was decarboxylated with chromic acid (Calvin et al. 1949); the acetate formed was isolated and degraded as described above. Succinate was decarboxylated by the method of Phares \& Long (1955). The specific activity of the methylene carbons of succinate was determined by subtracting the specific activity of the carboxyl carbons from the total specific activity obtained by wet-ashing. The validity of this method for determining the activity of the methylene carbons was established by decarboxylating a sample of synthetic succinate $2,3-{ }^{14} \mathrm{C}$. No radio-activity was released with decarboxylation and when the residual ethylenediamine was isolated on paper chromatograms (Buchanan, 1962), its specific activity was in excellent agreement with the specific activity of the original succinate.

For enzyme studies, the organism was grown in the Casitone medium containing $25 \mu$ moles $\mathrm{NaHCO}_{3} / \mathrm{ml}$., under $\mathrm{Na}_{2} \mathrm{CO}_{3}+$ pyrogallol seals. A volumetric flask of either 1 or 21 . capacity filled to the base of the neck was inoculated with $10 \mathrm{ml}$. of an actively growing culture and incubated for 3-4 days. Organisms were harvested by centrifugation, washed three times with $0.01 \mathrm{M}$-potassium phosphate buffer $(\mathrm{pH} 7.0)$ containing $0.01 \%(\mathrm{w} / \mathrm{v})$ neutralized cysteine $\mathrm{HCl}$. The packed cells were resuspended in this buffer to give a $50 \%(\mathrm{v} / \mathrm{v})$ suspension.

Like corynebacteria and lactobacilli (Gunsalus, 1955) the actinomyces organisms were difficult to break. Treatment with lysozyme, grinding with glass beads, sonic oscillation with a $12 \mathrm{kc}$. apparatus $(50 \mathrm{~W}$.), and treatment in a French pressure cell were ineffective in releasing soluble protein. The only procedures found to break the organisms were grinding with alumina or subjection to a $20 \mathrm{kc}$. (75 W.) sonic oscillator (Heat Systems Co., Great Neck, New York).

For alumina-broken preparations, 8-10 g. alumina was added per g. wet wt. organism, and the suspension was ground at $4^{\circ}$ in a Sorvall Omnimixer (Ivan Sorvall, Norwalk, Connecticut) for $10 \mathrm{~min}$. in $30 \mathrm{sec}$. bursts at $1 \mathrm{~min}$. intervals to prevent heating. For sonic preparations, suspensions of organism were subjected to sonic treatment at $4^{\circ}$ for $10 \mathrm{~min}$. in $30 \mathrm{sec}$. bursts at $1 \mathrm{~min}$. intervals to prevent heating. Treated suspensions were centrifuged for $15 \mathrm{~min}$. at $23,500 \mathrm{~g}$ at $4^{\circ}$ to remove debris and unbroken organisms. The precipitate was discarded; the supernatant fluid was dialysed for $4 \mathrm{hr}$ against $0.01 \mathrm{M}$-potassium phosphate buffer $(\mathrm{pH} \mathrm{7.0)}$ containing $0.01 \%$ (w/v) neutralized cysteine $\mathrm{HCl}$. When the oxidation or reduction of nicotinamide nucleotides (NAD) was to be measured, the dialysed extract was centrifuged for 
$60 \mathrm{~min}$. at $100,000 \mathrm{~g}$ in a preparative ultracentrifuge. The supernatant fraction, which contained the soluble enzymes, was saved; the black precipitate, which contained a very active $\mathrm{NADPH}_{2}$ oxidase system, was discarded.

Enzymes were assayed at room temperature $\left(25^{\circ} \pm 2^{\circ}\right)$. Oxidation and reduction of NAD were measured by the change in extinction at $340 \mathrm{~m} \mu$ with a Beckman DU spectrophotometer. Fructosediphosphate aldolase (Enzyme Commission, subsequently referred to as E.C., no. 4.1.2.13) was assayed according to Sibley \& Lehninger (1949) as modified by Bard \& Gunsalus (1950), glucosephosphate isomerase (E.C. 5.3.1.9) according to Slein (1955), phosphate acetyltransferase (E.C. 2.3.1.8) according to Stadtman (1955) based on the reaction of acetyl phosphate with hydroxylamine (Lipmann \& Tuttle, 1945), isocitrate dehydrogenase (E.C. 1.1.1.42) and malate dehydrogenase (E.C. 1.1.1.37) according to Ochoa (1955a,b), aconitate hydratase (E.C. 4.2.1.3) according to Anfinsen (1955), fumarate hydratase (E.C. 4.2.1.2) according to Massey (1955), and glutamate dehydrogenase (E.C. 1.4.1.3) according to Strecker (1955). Protein was estimated by the phenol method of Sutherland, Cori, Haynes \& Olsen (1949) with bovine serum albumin as a standard. For each enzyme, the initial rate was directly proportional to the protein concentration. The rates varied little in different preparations.

The chemicals used were of reagent grade and were obtained from commercial sources.

\section{RESULTS}

One of the most useful techniques in elucidating metabolic pathways in microorganisms is the use of ${ }^{14} \mathrm{C}$-labelled substrates (Wood, 1961). For heterotrophic organisms, an organic substrate labelled in a specific position is supplied to growing cultures and the fermentation products isolated and degraded to determine the positions of the label. For saccharolytic organisms such as Lactobacillus casei and Streptococcus faecalis (Gibbs, Dumrose, Bennet \& Bubeck, 1950), glucose $1-{ }^{14} \mathrm{C}$ and glucose ${ }^{6-14} \mathrm{C}$ have been used most frequently. In the Embden-Meyerhof pathway, $1-{ }^{14} \mathrm{C}$ and ${ }^{6-14} \mathrm{C}$ glucose are both converted to fermentation products, such as lactate, which show identical labelling patterns. When glucose is fermented by other mechanisms (for example, the oxidative pentose phosphate pathway) the lactate formed in glucose ${ }^{1-14} \mathrm{C}$ and glucose $6-{ }^{14} \mathrm{C}$ fermentations shows quite different labelling patterns.

Table 1 shows the results of the fermentation of glucose ${ }^{1-14} \mathrm{C}$ and glucose $6-{ }^{14} \mathrm{C}$ by Actinomyces naeslundii grown anaerobically in substrate amounts $(25 \mu \mathrm{m} . / \mathrm{ml}$.) of $\mathrm{CO}_{2}$ added to the medium as bicarbonate. The ratio of the fermentation products was essentially as is shown in equation (3). The radioactivity recovered in the formate, $\mathrm{CO}_{2}$ and carboxyl groups of lactate and succinate was low. This eliminated the oxidative pentose phosphate cycle, Entner-Doudoroff, and hexose monophosphate pathways (see review by Wood, 1961) as major mechanisms for glucose dissimilation. Based on radioactivity recovered in the formate, $\mathrm{CO}_{2}$ and carboxyl groups of acetate, formate and succinate, not more than $6 \%$ of the total glucose fermented was channelled through any one of these pathways.

In the Embden-Meyerhof pathway, the glucose 1-carbon and the glucose 6-carbon atoms are precursors of the methyl-carbon atoms of lactate, of acetate, and of a methylene carbon of succinate (assuming succinate synthesis from a $\mathrm{C}_{3}$ unit $+\mathrm{CO}_{2}$ ) Chemically the two methylene carbons of succinate are indistinguishable, and therefore 
the total activity in both carbons must be considered. In general, the degradation data in Table 1 fit these requirements for formation by the Embden-Meyerhof pathway. The specific activities of acetate, lactate and succinate were approximately $50 \%$ of the original ${ }^{14} \mathrm{C}$-glucose molecules. For unknown reasons, the specific activity of acetate isolated from the glucose $6-{ }^{14} \mathrm{C}$ fermentation was low and was only $33 \%$ of the original ${ }^{14} \mathrm{C}$-glucose. Of the total radioactivity in acetate and lactate, at least two-thirds resided in the methyl carbon atoms. Of the succinate, at least $90 \%$ of the total activity resided in the two methylene carbons.

\title{
Table 1. Fermentation of glucose $1{ }^{14} \mathrm{C}$ and glucose $6-{ }^{14} \mathrm{C}$ by Actinomyces naeslundii
}

\begin{abstract}
Organisms were grown anaerobically in $50 \mathrm{ml}$. Casitone medium $(0.5 \%, \mathrm{w} / \mathrm{v})$ containing either glucose $1{ }^{14} \mathrm{C}$ or glucose $6{ }^{14} \mathrm{C}$ with $25 \mu$ moles $\mathrm{NaHCO}_{3} / \mathrm{ml}$. under $\mathrm{Na}_{2} \mathrm{CO}_{3}+$ pyrogallol seals. The following specific activities and total c.p.m., respectively, were used: glucose $1-{ }^{14} \mathrm{C}$ 1012 c.p.m. $/ \mu$ mole and $12.75 \times 10^{5}$ c.p.m.; glucose $6-{ }^{14} \mathrm{C}, 601$ c.p.m. $/ \mu$ mole and $7 \cdot 25 \times 10^{5}$ c.p.m. Assimilated glucose was determined by counting samples of washed organisms at infinite thinness. Other experimental details are given in the text.
\end{abstract}

\begin{tabular}{|c|c|c|c|c|}
\hline & \multicolumn{2}{|c|}{$\begin{array}{l}\mu \text { moles } / 100 \mu \text { moles } \\
\text { glucose fermented }\end{array}$} & \multicolumn{2}{|c|}{$\begin{array}{l}\text { Specific activity of } \\
{ }^{14} \mathrm{C} \text {-products in \% of the } \\
\text { original }{ }^{14} \mathrm{C} \text {-glucose }\end{array}$} \\
\hline & $\underset{1^{1-14} \mathrm{C}}{\text { Glucose }}$ & $\underset{6-{ }^{-14} \mathrm{C}}{\text { Glucose }}$ & $\begin{array}{c}\text { Glucose } \\
1^{-14} \mathrm{C}\end{array}$ & $\begin{array}{c}\text { Glucose } \\
6^{-14} \mathrm{C}\end{array}$ \\
\hline $\mathrm{CO}_{2}$ remaining & - & - & $5 \cdot 0$ & $0 \cdot 2$ \\
\hline $\mathrm{CO}_{2}$ fixed & $52 \cdot 5$ & 54.9 & - & - \\
\hline $\mathrm{CH}_{3}-\mathrm{COOH}$ & $47 \cdot 1$ & $49 \cdot 7$ & $45 \cdot 2$ & $33 \cdot 6$ \\
\hline $\mathrm{CH}_{3}-$ & 一 & - & $40 \cdot 0$ & $21 \cdot 4$ \\
\hline$-\mathrm{COOH}$ & - & - & $7 \cdot 0$ & $9 \cdot 3$ \\
\hline $\mathrm{HCOOH}$ & $48 \cdot 2$ & 52.9 & $5 \cdot 8$ & $0 \cdot 8$ \\
\hline $\mathrm{CH}_{3}-\mathrm{CHOH}-\mathrm{COOH}$ & $21 \cdot 4$ & $23 \cdot 6$ & $52 \cdot 7$ & $48 \cdot 0$ \\
\hline $\mathrm{CH}_{3}-$ & - & - & $37 \cdot 8$ & $37 \cdot 8$ \\
\hline$-\mathrm{CHOH}-$ & - & - & $6 \cdot 6$ & $3 \cdot 8$ \\
\hline$-\mathrm{COOH}$ & - & - & $4 \cdot 0$ & $6 \cdot 5$ \\
\hline $\mathrm{HOOC}-\mathrm{CH}_{2}-\mathrm{CH}_{2} \mathrm{COOH}$ & 54.9 & $54 \cdot 5$ & $53 \cdot 1$ & $47 \cdot 5$ \\
\hline HOOC- & - & - & $2 \cdot 0$ & $0 \cdot 4$ \\
\hline$-\mathrm{CH}_{2}-$ & - & - & $23 \cdot 6$ & $23 \cdot 5$ \\
\hline Redox index & $0 \cdot 98$ & 0.98 & - & - \\
\hline Glucose assimilated & $14 \cdot 0$ & $10 \cdot 2$ & - & - \\
\hline Carbon recovery (\%) & 77.9 & $76 \cdot 7$ & - & - \\
\hline 14 Carbon recovery (\%) & $78 \cdot 0$ & $79 \cdot 4$ & - & - \\
\hline
\end{tabular}

Pertinent to demonstrating a particular metabolic pathway in an organism is the demonstration of its constituent enzymes. Aldolase is considered indicative of the Embden-Meyerhof pathway, and so far it has not been shown to function in other saccharolytic pathways (Buyze, van den Hamer \& De Haan, 1957). Table 2 shows that aldolase was present in cell-free extracts of Actinomyces naeslundii and that its capacity was relatively high (cf. McDonald, Cheldelin \& King, 1960). Extracts of a related organism, Actinomyces propionicus (Buchanan \& Pine, 1962), also showed aldolase activity, with a rate about two-thirds that observed in $A$. naeslundii, thus indicating the Embden-Meyerhof pathway is possibly widespread in this group of organisms. Glucosephosphate isomerase, an enzyme of the Embden-Meyerhof pathway, and phosphate acetyltransferase, which often occurs in anaerobic bacteria (Stadtman, 1955), were also present in $A$. naeslundii (Table 2).

In a previous study, Actinomyces naeslundii was grown anaerobically in ${ }^{14} \mathrm{CO}_{2}$ and 
glutamate and aspartate were isolated and degraded (Buchanan \& Pine, 1965). The labelling pattern observed in glutamate was consistent with its biosynthesis from $\alpha$ ketoglutarate, formed by the tricarboxylic acid cycle. This conclusion is supported by results of the present investigation which show that isocitric dehydrogenase, aconitase, and NADP-linked glutamic dehydrogenase were present in relatively high amounts in $A$. naeslundii (Table 2).

Table 2. Demonstration of certain enzymes in cell-free extracts of Actinomyces naeslundii

$\begin{array}{lr}\text { Fructosediphosphate aldolase } & 1 \cdot 6 \\ \text { Glucosephosphate isomerase } & 0 \cdot 5 \\ \text { Phosphate acetyltransferase } & 18 \cdot 0 \\ \text { Aconitate hydratase } & 1 \cdot 7 \\ \text { Isocitrate dehydrogenase } & 8 \cdot 5 \\ \text { Glutamate dehydrogenase (NADP linked) } & 7 \cdot 5 \\ \text { Malate dehydrogenase } & 59 \cdot 0 \\ \text { Fumarate hydratase } & 3 \cdot 8 \\ \text { Glucose-6-phosphate dehydrogenase } & 0 \cdot 5 \\ \text { Phosphogluconate dehydrogenase } & 2 \cdot 6 \\ \text { Other enzymes of oxidative pentose phosphate } & \\ \text { pathway } & 0.1 *\end{array}$

$\mu$ moles substrate
used/mg. protein/hr
1.6
0.5
18.0
1.7
8.5
7.5
59.0
3.8
0.5
2.6
$0.1 *$

* This value does not represent the activity of any single enzyme, but instead is the over-all rate of conversion of ribose 5-phosphate to glucose 6-phosphate.

The mechanism by which $\mathrm{CO}_{2}$ was incorporated into the carboxyl carbons of succinate by Actinomyces naeslundii was not determined unequivocally. However, a low but significant exchange reaction between ${ }^{14} \mathrm{CO}_{2}$ and the $\beta$-carboxyl carbon of oxaloacetate was demonstrated (Buchanan, 1962), and this provided evidence that the primary carboxylation reaction in $A$. naeslundii, leading to succinate, is the phosphopyruvate carboxylase (E.C. 4.1.1.32) reaction originally studied by Utter \& Kurahashi (1954). Oxaloacetate would then be reduced to succinate by a reversal of the malic dehydrogenase, fumarase and succinic dehydrogenase (E.C. 1.3.99.1) reactions. The present demonstration (Table 2) of fumarase and malic dehydrogenase activities in $A$. naeslundii extracts supports this conclusion.

Glucose-6-phosphate dehydrogenase (E.C. 1.1.1.49) and phosphogluconate dehydrogenase (E.C. 1.1.1.44) were demonstrated in extracts of Actinomyces naeslundii (Table 2). As based on the reduction of NADP with ribose 5-phosphate as substrate (Table 2), the other enzymes of the pentose cycle which convert ribose 5-phosphate to glucose 6-phosphate were also present. These data therefore indicate that $A$. naeslundii has a complete oxidative pentose phosphate cycle but, as pointed out above, its operation as a major mechanism of glucose breakdown in $A$. naeslundii was excluded on the basis of the glucose ${ }^{1-14} \mathrm{C}$ fermentation data (Table 1). These data indicated that, at most, $6 \%$ if the total glucose fermented could go by this pentose pathway. Similar results were obtained in independent glucose $1-{ }^{14} \mathrm{C}$ fermentations carried out under aerobic conditions (Buchanan, 1962), thus eliminating the possibility of its function as a major pathway in aerobic growth.

Because of its relation to Actinomyces naeslundii, A. propionicus was tested for certain enzymes found in $A$. naeslundii. Other than the aldolase mentioned above, 6- 
phosphogluconic dehydrogenase and isocitric dehydrogenase were found in extracts of $A$. propionicus, at essentially the same concentration as in A. naeslundii (Buchanan, 1962).

With the recognition that glycolysis was the major pathway used for the fermentation of glucose by Actinomyces naeslundii, and that the fermentation products depended on the availability and nature of the added electron acceptors, we tried to correlate the relative yields of organism to the energy theoretically released in a particular type of

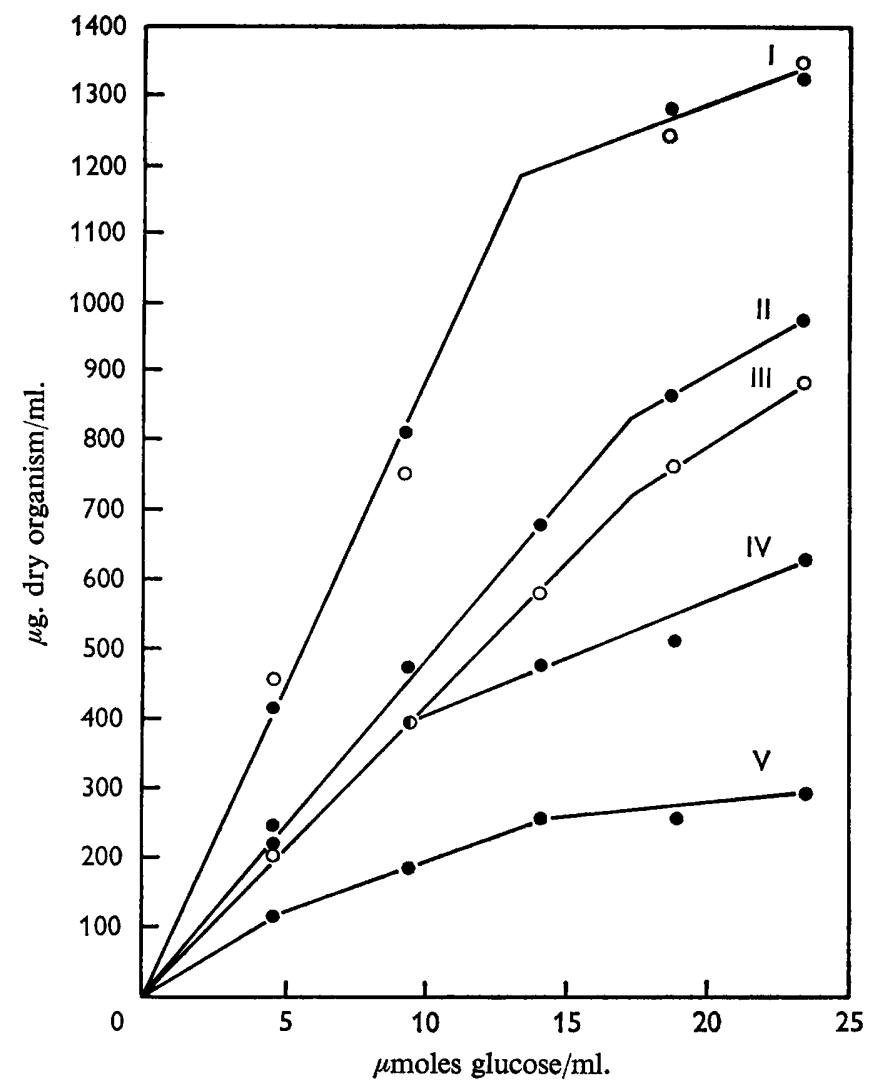

Fig. 1. Dependence of the yields of Actinomyces naeslundii on the conditions of culture. I, Aerobic growth in Casitone medium with $\mathrm{CO}_{2}=0$; without $\mathrm{CO}_{2}=0$. II, Anaerobic growth in Casitone medium with $\mathrm{CO}_{2}$. III, Anaerobic growth in casein hydrolysate medium with $\mathrm{CO}_{2}$. IV, Anaerobic growth in casein hydrolysate medium minus $\mathrm{CO}_{2}$ plus malate. V, Anaerobic growth in casein hydrolysate medium minus $\mathrm{CO}_{2}$. Cells were grown on a rotary shaker in test-tubes containing $5 \mathrm{ml}$. Casitone medium under $\mathrm{KH}_{2} \mathrm{PO}_{4}+\mathrm{Na}_{2} \mathrm{CO}_{3}$ seals to supply gaseous $\mathrm{CO}_{2}(\mathrm{I})$; in side-arm fermentation tubes (Pine, 1956) containing $50 \mathrm{ml}$. Casitone medium with $25 \mu$ moles $\mathrm{NaHCO}_{3} / \mathrm{ml}$. under $\mathrm{Na}_{2} \mathrm{CO}_{3}+$ pyrogallol seals (II); in $50 \mathrm{ml}$. volumetric flasks containing $48 \mathrm{ml}$. casein hydrolysate medium with $25 \mu$ moles $\mathrm{NaHCO}_{3} / \mathrm{ml}$. under either $\mathrm{Na}_{2} \mathrm{CO}_{3}+$ pyrogallol seals (III) or without $\mathrm{NaHCO}_{3}$ under $\mathrm{NaOH}+$ pyrogallol seals (IV, V). Sodium malate was added to IV to $0.5 \%(w / v)$. Above values represent the average growth observed in duplicate vessels. Aerobic tubes were inoculated with 1 drop of a homogenized $72 \mathrm{hr}$ culture diluted with water to an extinction of 0.5 ; anaerobic vessels were inoculated with the equivalent of $1 \mathrm{mg}$. dry wt. organisms. Growth was measured by the extinction at $600 \mathrm{~m} \mu$ in a Spectronic-20 colorimeter. Extinction was related to dry weight by reference to a standard curve. The abscissa represents the initial concentration of glucose in the medium. All cultures were incubated $96 \mathrm{hr}$; maximum growth was usually attained in $48 \mathrm{hr}$; the ordinate represents the maximum value attained for each culture. 
fermentation. The yields of organism obtained under various anaerobic or aerobic conditions of growth are given in Fig. 1. Except for anaerobic growth without $\mathrm{CO}_{2}$, the extent of growth in all cases was proportional to the initial glucose concentration, at least for the first two points. As observed previously (Pine \& Howell, 1956; Buchanan \& Pine, 1963), growth was better in the presence of $\mathrm{CO}_{2}$ or air, presumably owing in part to the additional energy released in pyruvate breakdown. In anaerobic growth without $\mathrm{CO}_{2}$, growth was not proportional to the initial glucose concentration, although it was approximately linear up to $9 \cdot 4 \mu$ moles glucose utilized $/ \mathrm{ml}$. The nonlinearity in the growth response was, in part, due to lack of aspartic acid, which could not by synthesized de novo without $\mathrm{CO}_{2}$ and which could not be assimilated when added to the culture medium because of the absence of a permease (Buchanan \& Pine, 1965).

Table 3. Yields of Actinomyces naeslundii under various conditions of growth

\begin{tabular}{|c|c|c|c|c|c|c|c|}
\hline $\begin{array}{l}\text { Curve of } \\
\text { Fig. } 1\end{array}$ & $\begin{array}{l}\text { Medium and } \\
\text { substrate }\end{array}$ & Conditions & $\begin{array}{l}\text { Glucose } \\
\text { oncentration } \\
\text { ( } \mu \text { mole } / \mathrm{ml} \text { ) }\end{array}$ & $Y^{*}$ & $\begin{array}{c}\text { Equation } \\
\text { no. } \\
\text { (see text) }\end{array}$ & $\begin{array}{l}\text { Net } \\
\text { ATP/mole } \\
\text { glucose* }\end{array}$ & $Y_{\mathrm{ATP}} \ddagger$ \\
\hline $\mathbf{I}$ & Casitone, glucose & Air or air $+\mathrm{CO}_{2}$ & $\begin{array}{l}4 \cdot 7 \\
9 \cdot 4\end{array}$ & $\begin{array}{l}87 \cdot 2 \\
86 \cdot 7\end{array}$ & $\begin{array}{l}4 \\
4\end{array}$ & $\begin{array}{l}4 \\
4\end{array}$ & $\begin{array}{l}21.8 \\
21.7\end{array}$ \\
\hline II & Casitone, glucose & Anaerobic $+\mathrm{CO}_{2}$ & $\begin{array}{r}4 \cdot 7 \\
9 \cdot 4 \\
14 \cdot 1\end{array}$ & $\begin{array}{l}48 \cdot 9 \\
51 \cdot 0 \\
48 \cdot 2\end{array}$ & $\begin{array}{l}3 \\
3 \\
3\end{array}$ & $\begin{array}{l}2 \cdot 8 \\
2 \cdot 8 \\
2 \cdot 8\end{array}$ & $\begin{array}{c}17 \cdot 5 \\
18 \cdot 2 \\
17 \cdot 2\end{array}$ \\
\hline III & $\begin{array}{l}\text { Casein hydrolysate, } \\
\text { glucose }\end{array}$ & Anaerobic $+\mathrm{CO}_{2}$ & $\begin{array}{r}4 \cdot 7 \\
9 \cdot 4 \\
14 \cdot 1\end{array}$ & $\begin{array}{l}42 \cdot 5 \\
41 \cdot 5 \\
41 \cdot 1\end{array}$ & $\begin{array}{l}3 \\
3 \\
3\end{array}$ & $\begin{array}{l}2 \cdot 8 \\
2 \cdot 8 \\
2 \cdot 8\end{array}$ & $\begin{array}{l}15 \cdot 2 \\
14 \cdot 8 \\
14 \cdot 7\end{array}$ \\
\hline IV & $\begin{array}{l}\text { Casein hydrolysate, } \\
\text { glucose + malate }\end{array}$ & Anaerobic, no $\mathrm{CO}_{2}$ & $9 \cdot 4$ & $40 \cdot 4$ & 5 & 4 & $10 \cdot 1$ \\
\hline V & $\begin{array}{l}\text { Casein hydrolysate, } \\
\text { glucose }\end{array}$ & Aneraobic, no $\mathrm{CO}_{2}$ & $4 \cdot 7$ & $24 \cdot 7$ & 1 & 2 & $12 \cdot 3$ \\
\hline
\end{tabular}

* $\mu$ g. dry wt. organism/ $\mu$ mole glucose fermented (Bauchop \& Elsden, 1960).

$\dagger$ Based on the fermentation equations shown in the text, in which the formation of 1 mole of acetate represents a net gain of 2 moles of ATP and 1 mole of lactate or succinate/mole ATP.

$\ddagger \mu$ g. dry wt. organisms $/ \mu$ mole ATP (Bauchop \& Elsden, 1960).

Anaerobic growth in the absence of $\mathrm{CO}_{2}$ but with malate (curve IV, Fig. 1) showed that malate partially replaced $\mathrm{CO}_{2}$ by functioning as a source of aspartate and as an electron acceptor to become succinate, pyruvate being converted to acetate and formate. Analysis of fermentations done in absence of $\mathrm{CO}_{2}$ but with added malate showed that Actinomyces naeslundii fermented glucose (at initial values not exceeding $10 \mu \mathrm{moles} / \mathrm{ml}$.) in accordance with the equation:

$$
\text { glucose }+2 \text { malate } \rightarrow 2 \text { formate }+2 \text { acetate }+2 \text { succinate. }
$$

At this low concentration of glucose, malate effectively substituted for $\mathrm{CO}_{2}$ with a yield of organism $80 \%$ of that observed for anaerobic growth with added $\mathrm{CO}_{2}$. At higher glucose concentrations, growth was no longer proportional to the glucose concentration and large amounts of lactate were formed. Analysis of the products showed the fermentation occurred according to the equation:

$$
2 \text { glucose }+2 \text { malate } \rightarrow 2 \text { formate }+2 \text { acetate }+2 \text { lactate }+2 \text { succinate. }
$$

Table 3 shows the yields of Actinomyces naeslundii calculated from data presented in Fig. 1, where growth was proportional to the added glucose. Growth is expressed in 
the $Y$ and $Y_{\mathrm{ATP}}$ units as defined by Bauchop \& Elsden (1960); the net moles ATP formed/mole glucose, as calculated from the appropriate fermentation equation given above, is shown also. For these calculations, we assumed that one net ATP is released in the formation of one mole of lactate or succinate; 2 ATP are formed in the production of acetate (one additional ATP being due to the breakdown of pyruvate to acetyl coenzyme $\mathrm{A}+\mathrm{CO}_{2}$ in air, or to acetyl coenzyme $\mathrm{A}+$ formate anaerobically). Bauchop \& Elsden (1960) defined the Y value as the g. dry wt. organism formed/mole glucose fermented; the value found for most organisms is 22 (Senez, 1962). The $Y$ values observed with $A$. naeslundii grown anaerobically with substrate concentrations of $\mathrm{CO}_{2}$ were $41 \cdot 1-51 \cdot 0$, depending on the growth medium. These values are at least twice those reported for most other organisms. However, Gunsalus \& Shuster (1961) reported a $Y$ value of 37.5 of Propionibacterium pentosaceum, an organism which in many ways is closely related to the actinomyces species (Stanier \& Van Niel, 1941; Buchanan \& Pine, 1962). As a result of the high $Y$ values observed with $A$. naeslundii, the $Y_{\mathrm{ATP}}$ values (g. dry wt. organism formed/theoretical mole ATP; Bauchop \& Elsden, 1960) are correspondingly 1.5-2 times higher than the $Y_{\text {АтP }}$ value of 10.5 observed for most organisms (Senez, 1962). Similar but somewhat higher values were obtained for aerobically grown $A$. naeslundii (Table 3 ). However, when the fermentation was homolactic (curve V, Fig. 1) or when malate was substituted for $\mathrm{CO}_{2}$ (curve IV, fig. 1), the $Y_{\text {ATP }}$ values were $10 \cdot 1$ and $12 \cdot 3$, respectively. If the $Y_{\text {ATP }}$ value of 10.5 be accepted as a universal constant (Senez, 1962), the data in Table 3 imply that $A$. naeslundii obtains additional energy in its glucose fermentation in the presence of $\mathrm{CO}_{2}$, perhaps at some point in the formation of succinate. However, this suggestion is complicated by the observation that the aspartate necessary for growth must be synhesized from a C $\mathrm{C}_{4}$-dicarboxylic acid (Buchanan \& Pine, 1965).

\section{DISCUSSION}

This communication shows that Actinomyces naeslundii ferments glucose primarily by the Embden-Meyerhof pathway. Enzymes of the oxidative pentose phosphate cycle are present, but isotopic data show that this is a minor pathway and does not account for more than $6 \%$ of the glucose fermented. The operation of phosphoketolase, although we have no direct evidence for its presence, could explain in part the low activity of ${ }^{14} \mathrm{C}$ in the methyl carbons of acetate when glucose $6{ }^{-14} \mathrm{C}$ was the substrate. It is possible that the pentose pathway is essential for providing certain intermediates, such as pentoses, which are used for growth and that it does not function in energy production. Such a role would restrict the function of the pentose pathway in A. naeslundii to the interconversion of sugars needed for biosynthesis.

The dependence of the fermentation products on the conditions of growth shows that the pyruvate (or phosphoenolpyruvate) formed from glucose can take alternative routes. In the absence of $\mathrm{CO}_{2}$ or $\mathrm{O}_{2}$, pyruvate is reduced to lactate. When substrate amounts of $\mathrm{CO}_{2}$ are present, lactate formation is relatively minor and $\mathrm{CO}_{2}$ is used in the synthesis of oxaloacetate and malate which function as electron acceptors to form succinate. $\mathrm{CO}_{2}$ is believed to be fixed into phosphoenolpyruvate to yield oxaloacetate, which is reduced to succinate by a reversal of the malic dehydrogenase, fumarase and succinic dehydrogenase reactions. The reduction of oxaloacetate to succinate requires four electrons, and four electrons are released in the conversion of a glucose molecule 
to two molecules of phosphoenolpyruvate. Therefore, when $\mathrm{CO}_{2}$ is present, a second molecule of phosphoenolpyruvate is free and is converted to acetate and formate, by way of pyruvate. This over-all process establishes a redox index of unity in the heterolactic fermentation as shown in equation (3). In aerobic growth, oxygen serves as an electron acceptor and glucose is oxidized to acetate, $\mathrm{CO}_{2}$ and $\mathrm{H}_{2} \mathrm{O}$; the mechanism by which the electrons react with oxygen has not been determined. The over-all mechanisms of glucose fermentation for Actinomyces naeslundii are depicted in Fig. 2, as determined from this and preceding reports (Buchanan \& Pine, 1963, 1965).

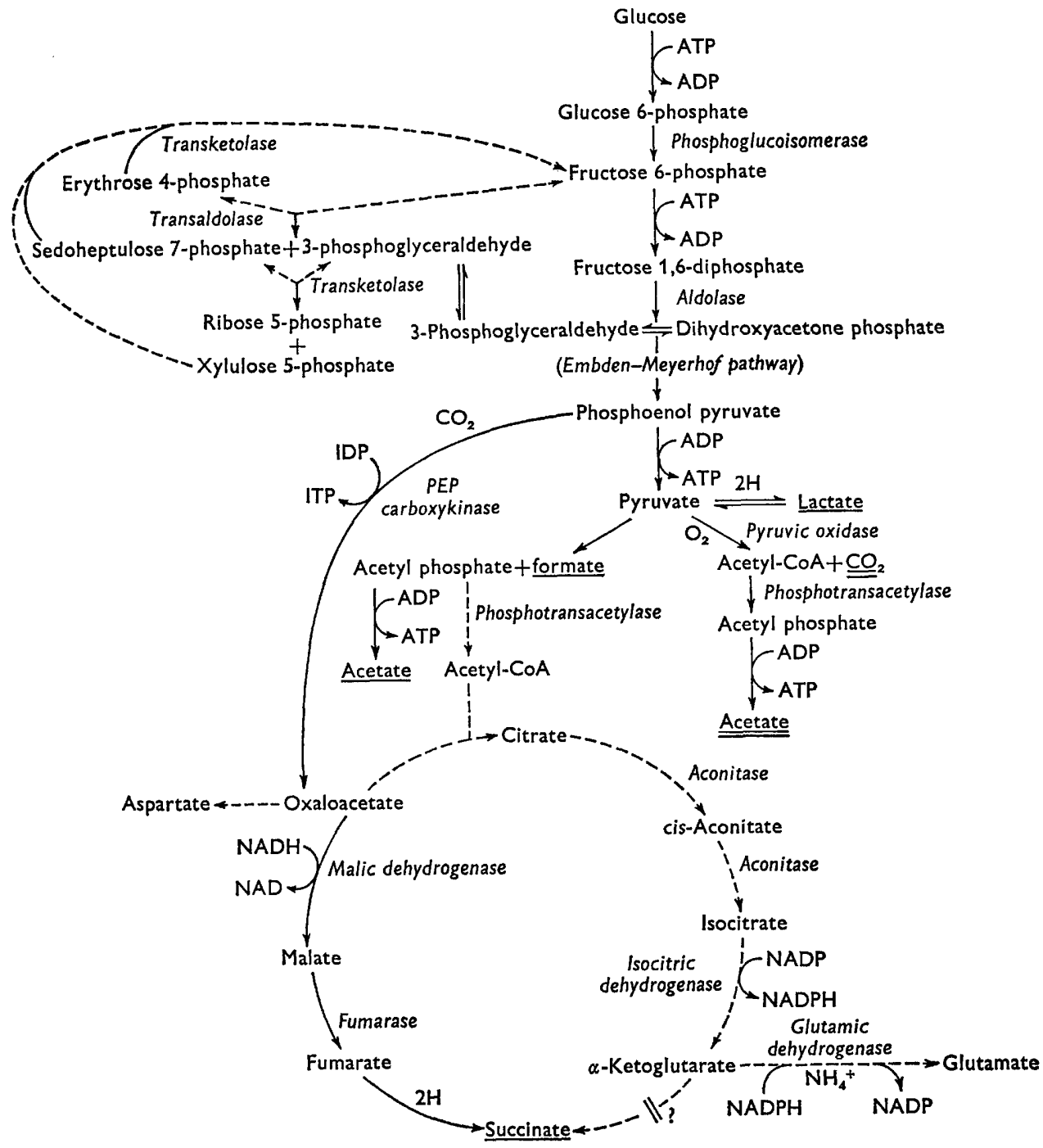

Fig. 2. Proposed mechanism of glucose breakdown by Actinomyces naeslundii. Major anaerobic fermentation products are singly underlined; major aerobic fermentation products are doubly underlined. Reactions believed to be involved principally in energy production are shown with solid arrows; reactions believed to be involved principally in biosynthesis are shown with broken arrows. The enzymes found in extracts are shown. 
The breakdown of pyruvate to acetyl coenzyme $\mathrm{A}$ or acetylphosphate releases additional energy for growth. Under conditions promoting pyruvate breakdown, the yields of Actinomyces naeslundii/glucose molecule are higher than for most other organisms. Whether or not this is peculiar to the actinomyces (and the propionibacteria; Gunsalus \& Shuster, 1961) is an interesting point that may be decided only by further experiments.

This investigation was supported by U.S. Public Health Service grants E-1866, SF 64, and 2E23.

\section{REFERENCES}

ANFinsen, C. B. (1955). Aconitase from pig heart. Meth. Enzym. 1, 695.

BARD, R. C. \& GUNSALUS, I. C. (1950). Glucose metabolism of Clostridium perfringens: existence of a metallo-aldolase. J. Bact. 59, 387.

BAUCHOP, T. \& ELSDEN, S. R. (1960). The growth of micro-organisms in relation to their energy supply. J. gen. Microbiol. 23, 457.

Buchanan, B. B. (1962). Studies on the Physiology and Metabolism of Actinomyces naeslundii. Ph.D. dissertation, Duke University.

Buchanan, B. B. \& PINE, L. (1962). Characterization of a propionic acid producing actinomycete, Actinomycetes propionicus, sp.nov. J. gen. Microbiol. 28, 305.

BuChanan, B. B. \& PiNe, L. (1963). Factors influencing the fermentation and growth of an atypical strain of Actinomyces naeslundii. Sabouraudia 3, 26.

Buchanan, B. B. \& PINE, L. (1965). Relationship of carbon dioxide to aspartic acid and glutamic acid in Actinomyces naeslundii. J. Bact. 89, 729.

BUSCH, H., HURlBert, R. B. \& POTTER, V. R. (1952). Anion exchange of acids of the citric acid cycle. J. biol. Chem. 196, 717.

Buyze, G., van den Hamer, J. A. \& De HaAn, P. G. (1957). Correlation between hexose-monophosphate shunt, glycolytic system and fermentation type in lactobacilli. Antonie van Leeuwenhoek 23, 345.

Calvin, M., Heidelberger, C., Reid, J. C., Tolbert, B. M. \& Yankwick, R. F. (1949). Isotopic Carbon, p. 93. New York: John Wiley and Sons Inc.

Cheftel, R. K., Munier, R. \& MAChebceur, M. (1953). Microchromatographie sur papier des acides aliphatiques hydrosolubles et non-volatils. III. Nouveaux couples de phases solvantes (alcalines et acides) pour la chromatographie à deux dimensions. Bull. Soc. chem. Biol. 35, 1085.

FRIEDEMANN, T. E. (1938). The identification and quantitative determination of volatile alcohols and acids. J. biol. Chem. 123, 161.

Gibis, M., Dumrose, R., Bennett, F. A. \& Bubeck, M. R. (1950). Bacterial fermentation of glucose to lactic acid studied with $\mathrm{C}^{14}$-glucose. J. biol. Chem. 184, 545 .

Gunsalus, I. C. (1955). Extraction of enzymes fom microorganisms (bacteria and yeast). Meth. Enzym. 1, 51.

Gunsalus, I. C. \& Shuster, C. W. (1961). Energy-yielding metabolism in bacteria. In The Bacteria, Ed. by I. C. Gunsalus and R. Y. Stanier, vol. 2, p. 1. New York: Academic Press.

KATZ, J., ABRAHAM, S. \& ChaIKoff, I. L. (1955). Analytical procedures using a combined combustiondiffusion vessel. An improved method for the degradation of carbon-14-labeled lactate and acetate. Anal. Chem. 27, 1955.

LIPMANN, F. \& TUTTLE, L. C. (1945). On the condensation of acetyl phosphate with formate or carbon dioxide in bacterial extracts. J. biol. Chem. 158, 505.

MASSEY, V. (1955). Fumarase. Meth. Enzym. 1, 729.

McDonald, J. K., Cheldelin, V. H. \& KING, T. E. (1960). Glucose catabolism in the ergot fungus, Claviceps purpurea. J. Bact. 80, 61.

OCHOA, S. (1955a). Isocitric dehydrogenase system (TPN) from pig heart. Meth. Enzym. 1, 699.

OCHOA, S. (1955 b). Malic dehydrogenase from pig heart. Meth. Enzym. 1, 735.

Phares, E. F. (1951). Degradation of labeled propionic and acetic acids. Archs Biochem. Biophys. 33, 173.

Phares, E. F. \& Long, M. V. (1955). The complete degradation of $\mathrm{C}^{14}$-labeled succinic acid and succinic anhydride by the Schmidt reaction. J. Am. chem. Soc. 77, 2556.

Pine, L. (1956). Fixation of carbon dioxide by Actinomyces and Lactobacillus bifidus. Proc. Soc. exp. Biol. Med. 93, 468.

PINE, L. (1960). Carbon dioxide fixation... a correction. Proc. Soc. exp. Biol. Med. 104, 702. 
PINe, L. \& Howell, A., Jun. (1956). Comparison of physiological and biochemical characters of Actinomyces spp. with those of Lactobacillus bifidus. J. gen. Microbiol. $15,428$.

Pine, L. \& WATSON, S. J. (1959). Evaluation of an isolation and maintenance medium for Actinomyces species and related organisms. J. Lab. clin. Med. 54, 107.

RABINowitz, J. C. \& BARKer, H. A. (1956). Purine fermentation by Clostridium cylindrosporum. I. Tracer experiments on the fermentation of guanine. J. biol. Chem. 218, 147.

SENEZ, J. C. (1962). Some considerations on the energetics of bacterial growth. Bact. Rev. $26,95$.

Sibley, J. A. \& Lehninger, A. L. (1949). Determination of aldolase in animal tissues. J. biol. Chem. $177,859$.

SleIN, M. W. (1955). Phosphohexoisomerases from muscle. Meth. Enzym. 1, 299.

Stadtman, E. R. (1955). Phosphotransacetylase from Clostridium kluyveri. Meth. Enzym. 1, 596.

STANIER, R. Y. \& VAN Niel, C. B. (1941). The main outlines of bacterial classification. J. Bact. 42, 437.

STRECKER, H. J. (1955). L-Glutamic dehydrogenase from liver. Meth. Enzym. 2, 220.

Sutherland, E. W., Cori, C. F., Haynes, R. \& Olsen, N. S. (1949). Purification of the hyperglycemic-glycogenolytic factor from insulin and from gastric mucosa. J. biol. Chem. 180, 825.

UTTER, M. F., \& KURAHASHI, K. (1954). Purification of oxalacetic carboxylase from chicken liver. J. biol. Chem. $207,787$.

Van Slyke, D. D., Plazin, J., \& Weisiger, J. R. (1951). Reagents for the Van Slyke-Folch wet carbon combustion. J. biol. Chem. 191, 299.

WooD, W. A. (1961). Fermentation of carbohydrates and related compounds. In The Bacteria, Ed. by I. C. Gunsalus and R. Y. Stanier vol. 2, p. 59. New York: Academic Press.

\section{Note added in Press}

Recent cell wall analyses of strain ATCC 10049 showed the major amino acids to be glutamic acid, alanine, lysine, and glycine. The major sugars were galactose and mannose. Large quantities of hexosamine were also present. On the basis of cell wall analysis this strain is more correctly classified as Actinomyces israelii than $A$. naeslundii. 